\title{
Light chain cardiac amyloidosis - a rare cause of heart failure in a young adult
}

Kevin Domingues ${ }^{1}, M D$

Mariana Saraiva', MD

Liliana Marta', MD

Isabel Monteiro', MD

Margarida Leal', MD

1. Department of Cardiology, Hospital Distrital de Santarém, Santarém, Portugal

\section{SUMMARY}

Cardiac amyloidosis is an infiltrative cardiomyopathy, resulting from amyloid deposition within the myocardium. In primary systemic (AL-type) amyloidosis, the amyloid protein is composed of light chains resulting from plasma-cell dyscrasia, and cardiac involvement occurs in up to $50 \%$ of the patients

We present a case of a 43-year-old man, with complaints of periodical swollen tongue and xerostomia, bleeding gums and haematuria for two months. His blood results showed normocytic anaemia, thrombocytopenia and a high spontaneous INR, therefore he was referred to the Internal Medicine clinic. In the first visit, he showed signs and symptoms of overt congestive heart failure and was referred to the emergency department. The electrocardiogram showed sinus tachycardia and low voltage criteria. Echocardiography showed biventricular hypertrophy with preserved ejection fraction, restrictive physiology with elevated filling pressures, thickened interatrial septum and atrioventricular valves, small pericardial effusion and relative "apical sparing" on 2D longitudinal strain. Cardiac MRI showed diffuse subendocardial late enhancement. Serum protein electrophoresis was inconclusive, however urine analysis revealed nephrotic range proteinuria, positive Bence Jones protein and an immunofixation test with a monoclonal lambda protein band. Abdominal fat biopsy was negative for Congo red stain, nevertheless a bone marrow biopsy was performed, revealing lambda protein monoclonal plasmocytosis, confirming the diagnosis of primary systemic amyloidosis.

This case represents a rare cause of heart failure in a young adult. Low-voltage QRS complexes and typical echocardiography features should raise the suspicion for cardiac amyloidosis. Prognosis is dictated by the level of cardiac involvement; therefore, early diagnosis and treatment are crucial.

\section{INTRODUCTION}

Restrictive cardiomyopathies are a heterogeneous group of myocardial diseases, whose hallmark echocardiographic finding is severe diastolic dysfunction. They are not common in daily practice, and their initial presentation is diverse. Several clinical, electrocardiographic and echocardiographic features may help in the diagnosis.

\section{CASE}

We present a case of a 43-year-old man, with history of schizophrenia, previously evaluated by different physicians because of swollen tongue and xerostomia, with an inconclusive work-up. He presented to his general practitioner with fatigue, bleeding gums and haematuria in the past two months. His blood test results showed normocytic anaemia, 


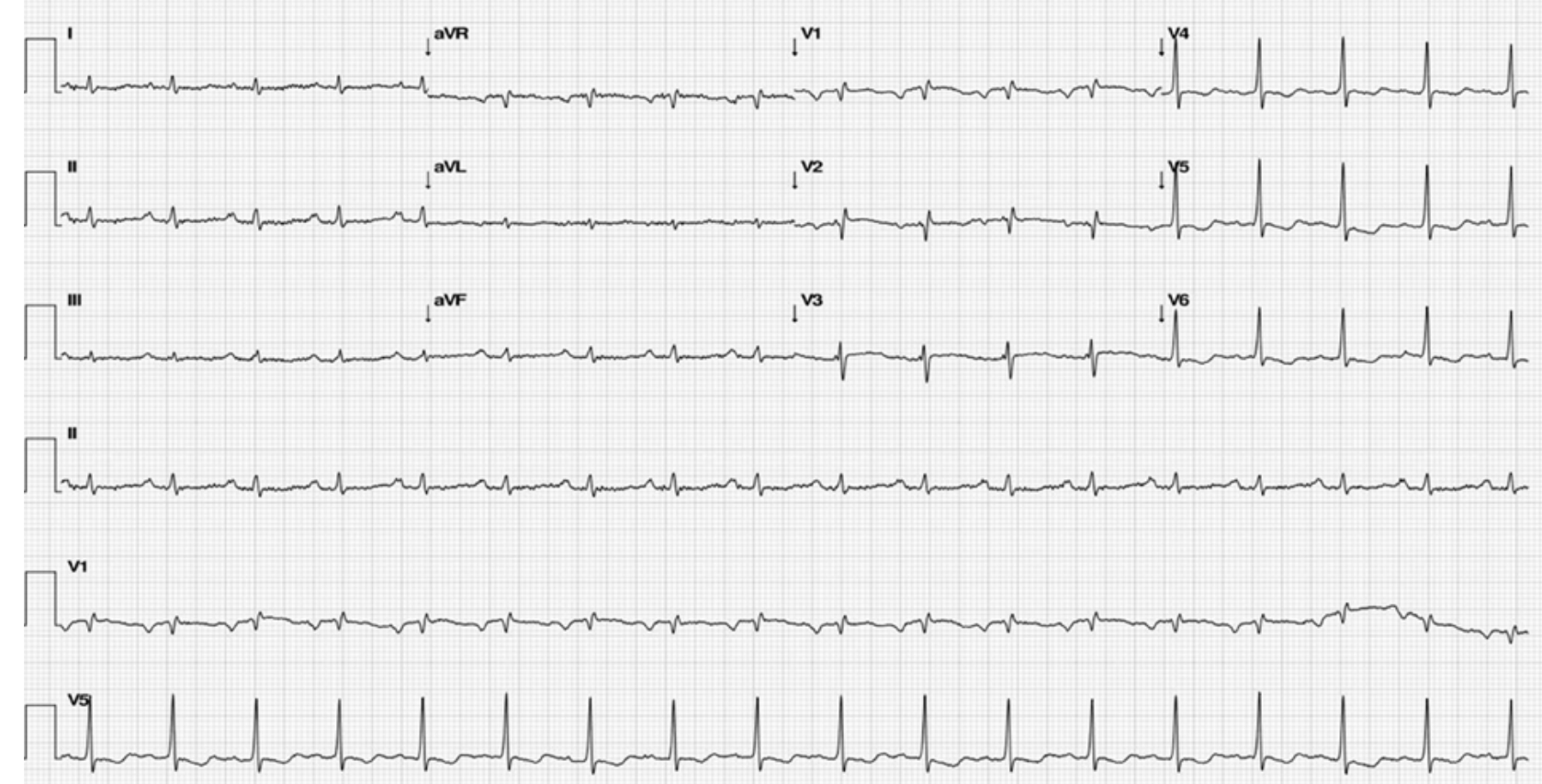

FIGURE 1 - Electrocardiogram: sinus tachycardia, low voltage criteria in the limb leads and diffuse nonspecific repolarization abnormalities.

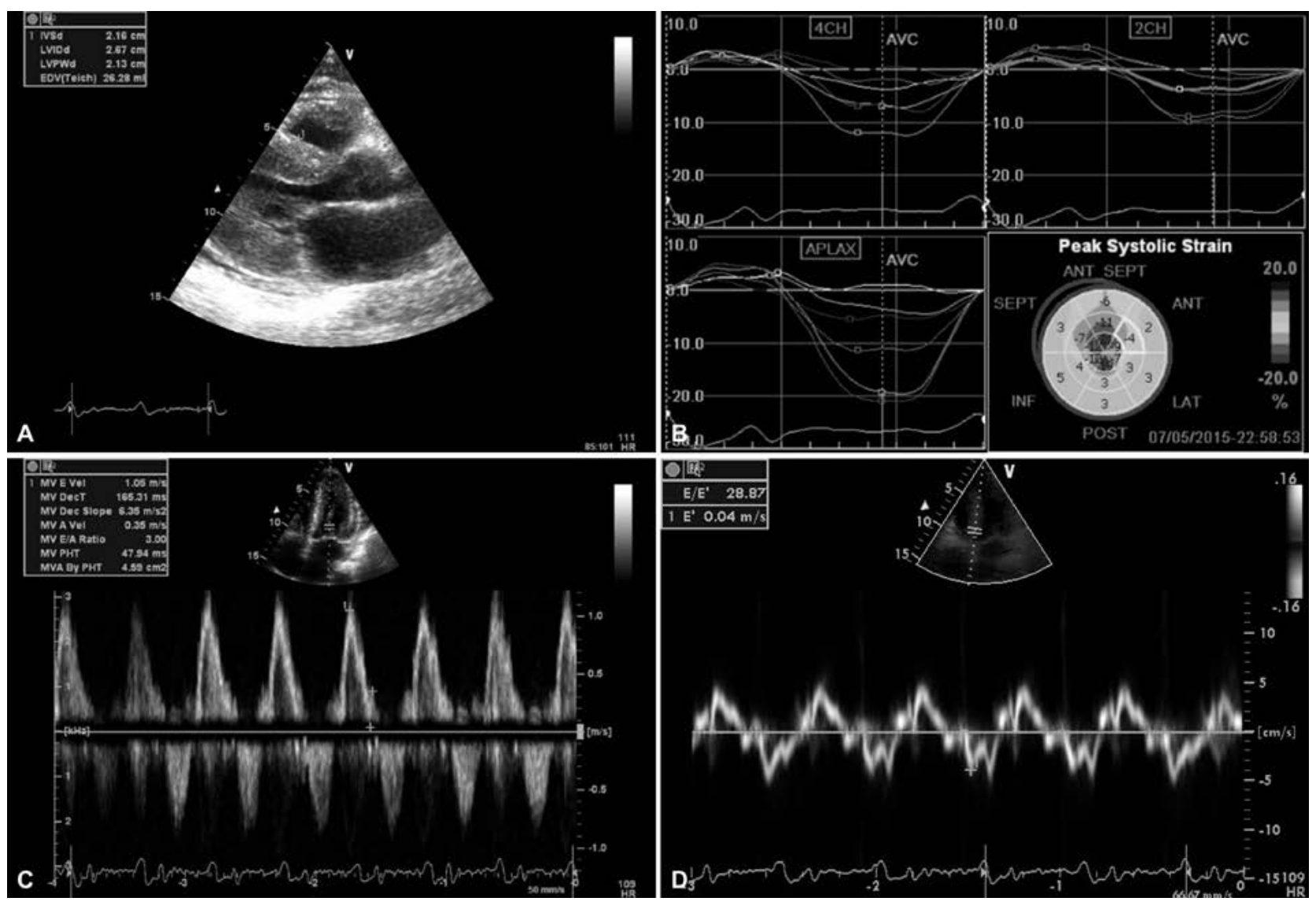

FIGURE 2 - Echocardiogram: A - Parasternal long axis view (still image): thickened left ventricular walls, dilated left atrium and small pericardial effusion. B - Speckle tracking longitudinal strain traces and bull's eye, with typical "apical sparing" pattern. C Transmitral flow pulsed wave Doppler showing a restrictive pattern. D - Tissue Doppler with low e' and high E/e' ratio, suggestive of high left atrial pressures.

VIDEO KEY: Echocardiogram with parasternal long and short axis and apical four chamber views and 2D speckle tracking longitudinal strain bull's eye. Typical cardiac amyloidosis features are present: left ventricular hypertrophy with granular appearance, dilated atria, thickened atrioventricular valves and interatrial septum, small pericardial effusion and "apical sparing" pattern. 
thrombocytopenia and a high spontaneous INR, therefore he was referred to the Internal Medicine clinic. In the first visit, he showed signs and symptoms of overt congestive heart failure and was referred to the emergency department. Chest radiography revealed interstitial oedema and bilateral pleural effusion and the electrocardiogram (ECG) showed sinus tachycardia and low voltage criteria (Figure 1). His hemogram and INR were similar to the previous, and had elevated alkaline phosphatase and gamma glutamyl transferase, high BNP and slight elevation of troponin and creatinine. Echocardiography showed biventricular hypertrophy with preserved ejection fraction, restrictive physiology with elevated filling pressures and relative "apical sparing" on 2D longitudinal strain. He also had thickened interatrial septum and atrioventricular valves and a small pericardial effusion (Figure 2; Video). He was admitted to the Cardiology Department for medical treatment, with progressive clinical improvement. Diagnostic work-up showed hypoalbuminemia, low levels of factors $\mathrm{V}$ and $\mathrm{X}$, antithrombin III and protein $\mathrm{C}$, elevated b2-microglobulin, ferritin and erythrocyte sedimentation rate, while the serum protein electrophoresis was inconclusive. Alpha-galactosidase levels were borderline low. Abdominal echography was not suggestive of chronic liver disease. Cardiac MRI showed diffuse subendocardial late enhancement. A 24-hour urine collection revealed nephrotic range proteinuria, positive Bence Jones protein and an immunofixation test with a monoclonal lambda protein band. Abdominal fat biopsy was negative for Congo red stain and the genetic study was also negative for mutations in the TTR and GLA genes. Nonetheless, a bone marrow biopsy was performed and it was no- table for lambda protein monoclonal plasmocytosis, accounting for $80 \%$ of the total cellularity, confirming the diagnosis of primary systemic (AL-type) amyloidosis. He was considered a poor candidate to autologous stem-cell transplantation, due to advanced cardiac involvement, and was started on chemotherapy (CyBORD protocol). Seven cycles were administered, with excellent tolerability and response. The patient is currently on NYHA class II, two years after the initial admission, under regular haematology and cardiology follow-up.

\section{DISCUSSION}

This case represents a rare cause of heart failure in a young adult. Cardiac amyloidosis is an infiltrative cardiomyopathy, resulting from amyloid deposition within the myocardium ${ }^{1,2}$. In primary systemic (ALtype) amyloidosis, the amyloid protein is composed of light chains resulting from plasma-cell dyscrasia ${ }^{2}$, and cardiac involvement occurs in up to $50 \%$ of the patients ${ }^{3}$. Macroglossia, nephrotic syndrome, bleeding and hepatomegaly are common clues to diagnosis ${ }^{4}$. Low-voltage QRS complexes and typical echocardiography features should in turn raise the suspicion for cardiac amyloidosis $\left(^{2}\right)$. The abdominal fat biopsy has a sensitivity of around $80 \%^{2,4,5}$, therefore other histologic studies should be performed if the result is negative ${ }^{2}$. Prognosis is dictated by the level of cardiac involvement $(<6$ months after the onset of heart failure, without treatment), therefore early diagnosis and treatment are crucial $1,2,4$.

Conflict of interests: None to declare

Funding: None.

\footnotetext{
RESUMO

A amiloidose cardíaca corresponde a uma miocardiopatia infiltrativa, resultante do depósito da proteína amiloide no miocárdio. Na amiloidose sistêmica primária (tipo AL), a proteína amiloide é composta por cadeias leves que resultam de discrasia dos plasmócitos, havendo envolvimento cardíaco em até $50 \%$ dos doentes.

Apresentamos o caso de um homem de 43 anos, com queixas de edema periódico da língua e xerostomia, hemorragia gengival e hematúria há dois meses. Analiticamente havia a destacar anemia normocítica, trombocitopenia e um INR alto espontâneo, pelo que foi referenciado à consulta de Medicina Interna. Na primeira consulta, apresentou-se com sinais de insuficiência cardíaca congestiva franca, pelo que foi referenciado ao Serviço de Urgência. O eletrocardiograma demonstrou taquicardia sinusal e critérios de baixa voltagem. O ecocardiograma revelou hipertrofia biventricular com fração de ejeção preservada, fisiologia restritiva com elevação das pressões de enchimento, espessamento do septo interauricular e das válvulas auriculoventriculares, derrame pericárdico ligeiro e padrão de apical sparing no strain longitudinal 2D. Realizou ainda ressonância magnética cardíaca, que mostrou realce tardio subendocárdico difuso. A eletroforese das proteínas foi inconclusiva, contudo a análise da urina revelou proteinúria no espectro nefrótico, presença de proteína de Bence Jones e um teste de imunofixação com uma banda monoclonal de cadeias lambda. A biópsia da gordura abdominal foi negativa. Não obstante, foi realizada uma biópsia da medula óssea, verificando-se plasmocitose monoclonal lambda, o que confirmou o diagnóstico de amiloidose primária sistêmica.

Este caso representa uma causa rara de insuficiência cardíaca no jovem adulto. A baixa voltagem no eletrocardiograma e os achados ecocardiográficos típicos devem fazer suspeitar de amiloidose cardíaca. O prognóstico é ditado pelo nível de envolvimento cardíaco, motivo pelo qual o diagnóstico e o tratamento precoces são essenciais.
} 


\section{REFERENCES}

1. Quarta CC, Kruger JL, Falk RH. Cardiac amyloidosis. Circulation. 2012;126(12). doi:10.1161/CIRCULATIONAHA.111.069195.

2. Falk RH, Alexander KM, Liao R, Dorbala S. AL (Light-Chain) Cardiac Amyloidosis: A Review of Diagnosis and Therapy. J Am Coll Cardiol. 2016;68(12):1323-1341. doi:10.1016/j.jacc.2016.06.053.

3. Mohty D, Damy T, Cosnay P, et al. Cardiac amyloidosis: Updates in diagnosis and management. Arch Cardiovasc Dis. 2013;106(10):528-540. doi:10.1016/j.acvd.2013.06.051
4. Grogan M, Dlspenzieri A, Gertz MA. Light-chain cardiac amyloidosis: Strategies to promote early diagnosis and cardiac response. Heart. 2017;103(14):1065-1072. doi:10.1136/heartjnl-2016-310704.

5. Quarta CC, Gonzalez-Lopez E, Gilbertson |A, et al. Diagnostic sensitivity of abdominal fat aspiration in cardiac amyloidosis. Eur Heart J. 2017;38(24):1905-1908. doi:10.1093/eurheartj/ehx047. 